\title{
PENGARUH PENDIDIKAN KESEHATAN SEBAYA PADA PERSEPSI DAN PRAKTIK SKRINING UNTUK KANKER SERVIKS DI KAB. MALANG (STUDI SEBELUM DAN SESUDAH)
}

\section{Effects Of Peer Health Education On Perception And Practice Of Screening For Cervical Cancer in Malang ( Before And After Study)}

\author{
Riska Faraswati ${ }^{1}$ \\ 1. Stikes Hafshawaty Pesantren Zainul Hasan
}

\section{Riwayat artikel \\ Diajukan: September 2020 \\ Diterima: Maret 2021. \\ PenulisKorespondensi: \\ - Riska Faraswati \\ - Stikes Hafshawaty Pesantren Zainul Hasan \\ - Riskafaraswati.RF@g $\underline{\text { mail.com }}$}

\section{Kata Kunci:}

Kanker Serviks, Skrining, Pendidikan Sebaya, Persepsi, Praktik

\begin{abstract}
Abstrak
Pendidikan wanita yang efektif terkait pencegahan kanker serviks telah terbukti memperluas kesadaran dan pengambilan keputusan skrining. Bagaimanapun, mempertahankan jumlah wanita yang mau melakukan skrining memerlukan upaya. Pendidikan kesehatan sebaya terbukti sebagai alat yang efektif mempengaruhi perubahan perilaku yang bersifat persisten. Tujuan dari penelitian ini guna meniali efektivitas pendidikan kesehatan sebaya terhadap persepsi, kesediaan wanita untuk melakukan skrining, dan praktik skrining kanker serviks.

Studi intervensi sebelum dan sesudah dilakukan pada wanita usia reproduktif di desa Dau, Kabupaten malang. Multistage sampling digunakan untuk memilih 300 wanita sebagai subjek penelitian. Pendidikan kesehatan sebaya diberikan satu kali setiap bulan selama 3 sesi berturut-turut selama 3 bulan. Data dikumpulkan sebelum dan setelah perlakuan dengan menggunakan kuesioner yang telah diuji sebelumnya.

Hasil uji statistik menunjukkan terdapat perbedaan persepsi akan manfaat deteksi dini kanker serviks pada peserta penyuluhan dengan nilai $p$ value $(0,02)<\alpha(0,05)$. Dari analisis data yang diperoleh diketahui bahwa persepsi akan manfaat skrining dipengaruhi status perkawinan, paritas, tingkat pendidikan, dan status pekerjaan ( $\mathrm{p}$ $<0,05)$. Pendidikan kesehatan sebaya adalah teknik yang menarik untuk memperbaiki pemahaman wanita akan manfaat skrining kanker serviks dan ini berimbas pada meningkatnya jumlah wanita yang melakukan skrining kanker serviks
\end{abstract}

\section{Abstract}

Effective female education on cervical cancer avoidance has been appeared to extend mindfulness and take-up of screening. However, maintaining the number of women who are willing to be screened requires effort. Peer health education is proven to be an effective tool in influencing persistent behavior change. The purpose of this study was to assess the effectiveness of peer health education on perceptions, women's willingness to do screening, and cervical cancer screening practices Intervention studies before and after were carried out on women of reproductive age in Dau village, Malang district. Multistage sampling was used to select 300 women as research subjects. Peer health education is given once a month for 3 consecutive sessions for 3 months. Data were collected before and after treatment using a questionnaire that had been tested previously. The results of statistical tests showed that there were differences in perceptions of the benefits of early detection of cervical cancer among extension participants with a $\mathrm{p}$ value $(0.02)<\alpha(0.05)$. From the analysis of the data obtained, it is known that the perception of the benefits of screening is influenced by marital status, parity, education level, and employment status $(\mathrm{p}<0.05)$. Peer health education is an interesting technique to improve women's understanding of the benefits of cervical cancer screening and this has resulted in an increasing number of women being screened for cervical cancer. 


\section{Pendahuluan}

Data WHO (World Health Organization) di tahun 2018; menunjukkan kanker serviks menduduki posisi keempat dari 570.000 kasus baru di semua jenis kanker yang menyerang wanita (World Health Organization, 2019). Di Indonesia tahun 2018, dari sekitar 188.231 penderita baru semua jenis kanker yang menyerang wanita $\pm 17,2 \%$ (32.469) adalah kanker serviks dan $8,8 \%$ atau \pm 18.279 meninggal karena kanker serviks (WHO, 2019).

Banyak bukti yang konsisten menyatakan bahwa infeksi human papillomavirus risiko tinggi (hrHPV) berimplikasi sebagai agen penyebab kanker serviks. Infeksi ini umum terjadi, terjadi pada sebagian besar wanita yang aktif secara seksual selama hidup mereka. 16 dan 18 jenis terdeteksi pada $70 \%$ lesi intraepitelial skuamosa tingkat tinggi (HGSIL) serta pada kasus kanker serviks invasif (Johnson et al., 2019). Sementara sebagian besar infeksi sembuh tanpa konsekuensi klinis selama beberapa tahun, infeksi persisten dapat menyebabkan lesi serviks prakanker tingkat tinggi (seperti neoplasia intraepitel serviks [CIN] derajat 2 dan 3) yang dapat berkembang menjadi kanker serviks selama periode 30 tahun (Oyervides-Muñoz et al., 2018).

Perkembangan yang lambat ini memungkinkan banyak kesempatan untuk mendeteksi dan mengobati lesi ini, sehingga tidak berubah menjadi kanker. Deteksi awal mampu meningkatkan peluang keberhasilan pengobatan kanker adekuat dan efektif sehingga prognosisnya baik dan prosentase tingkat kelangsungan hidup lebih baik (survival rate) penderita kanker turut meningkat (Allemani et al., 2015; Allemani et al., 2018).

Terdapat beberapa jenis tes skrining untuk kanker serviks seperti tes sitologi konvensional (Pap smear), sitologi berbasis cairan, inspeksi visual dengan asam asetat (IVA) dan Lugol's iodine (VILI), dan tes DNA Human papilloma virus (HPV)(Kemenkes RI, 2018). Tingkat serapan skrining kanker serviks pada wanita
Indonesia sangat rendah dan tidak terkait dengan tingkat kesadaran. Jumlah wanita di Jawa Timur yang melakukan skrining kanker 92.345 dengan temuan 31.001 kasus kanker serviks dan kanker payudara yang dilaporkan (Pusat Data dan Informasi KemenKes RI, 2015). Deputi BKKBN, Dwi Listyawardani menyampaikan jumlah perempuan yang melakukan deteksi dini kanker serviks baru 5 persen di seluruh Indonesia. Hal ini disebabkan karena ketidaktahuan dan minim kesadaran (Puspita, 2019).

Beberapa alasan mengapa wanita yang mengidap kanker serviks invasif tidak pernah pap smear dengan alasan ekonomi (Utami, 2013), kurangnya pengetahuan atau kesadaran; faktor-faktor yang dapat diperbaiki dengan pendidikan kesehatan (Siagian, 2015; Dinengsih et al., 2018). Pendidikan wanita yang efektif terkait skrining dan kanker serviks, telah diidentifikasi sebagai metode untuk meningkatkan kesadaran dan pemanfaatan layanan akan skrining kanker serviks (Ahmed et al., 2014; Luh et al., 2018). Relevansi pendidikan sebaya dengan kesehatan terletak pada kemampuannya untuk mengatasi dasar sosial yang berdampak pada kesehatan. Pendidikan sebaya mengacu pada difusi perilaku inovasi. teori yang menyatakan bahwa "individu tertentu dari populasi tertentu bertindak sebagai agen perubahan dengan menyebarkan informasi dan mempengaruhi norma kelompok dalam komunitas mereka" (Nurhadi, 2017). Namun, ada bukti lokal yang sangat terbatas tentang efek intervensi pendidikan kesehatan yang relevan konteks pada pengendalian kanker serviks.

Studi ini dilakukan untuk memeriksa apakah pendidikan kesehatan sebaya tentang kanker serviks dan skrining kanker serviks memberikan pengaruh terhadap persepsi wanita tentang kanker serviks dan skrining serta praktik skrining untuk penyakit tersebut. Studi ini memberikan pengetahuan baru tentang keefektifan intervensi pendidikan kesehatan sebaya yang sesuai konteks pada persepsi dan praktik skrining 
untuk kanker serviks di Kecamatan DauKab. Malang.

\section{Metodologi}

Penelitian berupa studi intervensi berbasis komunitas menggunakan desain sebelum dan sesudah. Studi ini dilakukan di kecamatan Dau-Kab. Malang. Populasi penelitian adalah wanita usia subur yang yang berusia 21 tahun atau lebih; saat ini aktif secara seksual atau telah di masa lalu; dan tidak pernah didiagnosis dengan kanker apa pun, memenuhi syarat untuk penelitian ini serta bertempat tinggal di wilayah studi. Dipilih usia 21 tahun guna menghindari pengobatan lesi yang tidak diperlukan dan di usia tersebut perubahan kanker serviks secara signifikan ditemukan diusia lebih dari 21 tahun (WHO, 2012a).

Jumlah sampel yang digunakan 300 responden, yang diambil dengan tehnik multistage sampel. Seluruh responden akan diberikan sesi pendidikan kesehatan sebaya tentang kanker servks dan pencegahannya secara berulang selama 3 bulan berturutturut dengan jumlah sesi pertemuan 3 hingga 6 sesi. Setiap sesi kelompok terdiri dari 4560 menit; Kegiatan ini diikuti dengan 15-30 menit klarifikasi dan umpan balik.

Data dikumpulkan sebelum dan setelah intervensi diberikan menggunakan kuesioner terstruktur yang telah teruji. Rincian isi materi pendidikan kesehatan sebaya tidak diberikan sebelum pengumpulan data dasar guna menghilangkan persepsi yang bias. Data dianalisis dengan SPSS. Variabel yang diukur adalah persepsi risiko individu untuk kanker serviks dan manfaat skrining, kemauan untuk skrining, praktik skrining yang sebenarnya, metode yang disukai, frekuensi skrining dan alasan skrining. Uji chi-square dilakukan untuk menilai signifikansi statistik dari perbedaan dan asosiasi yang diamati. Analisis regresi logistik faktor yang terkait dengan skrining untuk kanker serviks di antara wanita yang telah diskrining untuk kanker serviks. Signifikansi statistik ditetapkan pada nilai $p$ $<0,05$.

\section{Hasil dan Pembahasan}

Sebanyak 300 kuesioner dibagikan kepada 300 peserta yang direkrut sebelum intervensi; 285 di antaranya telah diisi dengan tepat dan cocok untuk analisis. Beberapa kuesioner dibuang karena tidak diisi secara lengkap; beberapa pertanyaan yang tidak boleh dilewati tidak dijawab. Beberapa kuesioner dibuang karena perbedaan jawaban yang tercatat. Setelah intervensi, 2 peserta lagi tidak dapat ditindaklanjuti, jadi total diperoleh 283 tanggapan pasca intervensi.

Usia rata-rata responden adalah $48( \pm$ 9,7) tahun, dan proporsi tertinggi berada pada kategori usia 45-54 tahun. Mayoritas responden sudah menikah, 208 (73\%). Proporsi responden tertinggi telah menyelesaikan pendidikan tinggi, 142 $(49,8 \%)$. Mayoritas dari mereka bekerja (dibayar atau mandiri): 199 (69,8\%) bekerja, $50(17,5 \%)$ bekerja sendiri. Sebagian besar responden memiliki empat anak atau lebih, $121(42,5 \%)$.

Tabel 1. Karakteristik sosio-demografis responden

\begin{tabular}{|c|c|c|}
\hline Variabel & & $\begin{array}{c}\text { Frequency } \\
(\%) \\
(\mathbf{N}=\mathbf{2 8 5})\end{array}$ \\
\hline \multirow[t]{4}{*}{ Usia } & $25-34$ & $18(6.3)$ \\
\hline & $35-44$ & $63(22.1)$ \\
\hline & $45-54$ & $133(46.7)$ \\
\hline & $>54$ & $71(24.9)$ \\
\hline \multirow{6}{*}{$\begin{array}{l}\text { Status } \\
\text { pernikahan }\end{array}$} & Menikah & $208(73)$ \\
\hline & Belum menikah & $17(6)$ \\
\hline & Cerai/terpisah & 0 \\
\hline & Janda & $60(21)$ \\
\hline & Co- & 0 \\
\hline & $\begin{array}{l}\text { habiting/tinggal } \\
\text { dengan patner }\end{array}$ & \\
\hline \multirow[t]{9}{*}{ Pendidikan } & Tidak tamat SD & 0 \\
\hline & Lulus SD & $16(5.6)$ \\
\hline & Tidak tamat & $10(3.5)$ \\
\hline & SMP & $46(16.1)$ \\
\hline & Tamat SMP & $13(4.6)$ \\
\hline & Tidak tamat & $142(49.8)$ \\
\hline & SMA & $58(20.4)$ \\
\hline & Tamat SMA & \\
\hline & Sarjana & \\
\hline Status & Pekerja dibayar & $199(69.8)$ \\
\hline \multirow[t]{3}{*}{ Pekerjaan } & Wiraswasta & $50(17.5)$ \\
\hline & Tidak bekerja & $18(6.3)$ \\
\hline & Mahasiswa & $18(6.3)$ \\
\hline \multirow[t]{2}{*}{ Paritas } & 1 & $30(10.5)$ \\
\hline & 2 & $29(10.2)$ \\
\hline
\end{tabular}




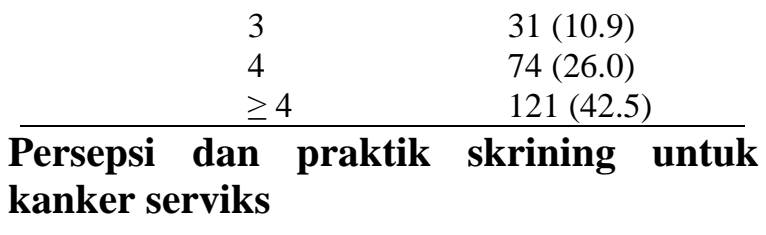

Persepsi peserta dan praktik skrining untuk kanker serviks disajikan pada Tabel 2. Setelah intervensi pendidikan kesehatan sebaya, proporsi peserta yang menganggap kanker serviks sama seriusnya sebagai kanker lainnya secara signifikan meningkat menjadi $219(77,4 \%)$ dengan $(p<0,001)$; dan sadar bahwa dirinya juga berisiko terkena kanker serviks, $113(40 \%)(p=$ $0,01)$. Proporsi wanita yang merasa skrining akan sangat bermanfaat juga meningkat secara signifikan dari $145(50,9 \%)$ menjadi $195(68,9 \%)$ dengan $p=0,01$.

Tabel 2. Persepsi tentang kanker serviks dan

\begin{tabular}{|c|c|c|c|}
\hline $\begin{array}{l}\text { Variabel } \\
\text { Persepsi }\end{array}$ & $\begin{array}{c}\text { Sebelum } \\
\text { intervens } \\
\mathrm{i} \\
(\mathrm{N}= \\
285) ; \mathrm{n} \\
(\%)\end{array}$ & $\begin{array}{c}\text { Setelah } \\
\text { intervensi } \\
(\mathrm{N}=283) ; \\
\mathrm{n}(\%)\end{array}$ & $\begin{array}{c}\mathrm{p}- \\
\text { value }\end{array}$ \\
\hline \multicolumn{4}{|l|}{$\begin{array}{l}\text { Persepsi } \\
\text { tingkat }\end{array}$} \\
\hline keparahan & 153 & 0 & - \\
\hline Tidak parah & $(53.7)$ & $219(77.4)$ & $<0.00$ \\
\hline Serius & 131 & $64(22.6)$ & 1 \\
\hline seperti & $(45.9)$ & & $<0.00$ \\
\hline kanker & $1(0.4)$ & & 1 \\
\hline lainnya & & & \\
\hline $\begin{array}{l}\text { Tidak } \\
\text { separah } \\
\text { kanker } \\
\text { lainnya }\end{array}$ & & & \\
\hline Persepsi & & & \\
\hline risiko & $74(26)$ & $113(40)$ & 0.01 \\
\hline $\begin{array}{l}\text { individu } \\
\text { Beresiko } \\
\text { Tidak } \\
\text { beresiko }\end{array}$ & $211(74)$ & $170(60)$ & 0.01 \\
\hline $\begin{array}{l}\text { Persepsi } \\
\text { manfaat }\end{array}$ & $98(34.4)$ & $33(11.7)$ & 0.001 \\
\hline skrining & 145 & $195(68.9)$ & 0.01 \\
\hline $\begin{array}{l}\text { Tidak } \\
\text { menguntun } \\
\text { gkan }\end{array}$ & $\begin{array}{c}(50.9) \\
42(14.7)\end{array}$ & $55(19.4)$ & 0.17 \\
\hline $\begin{array}{l}\text { Sangat } \\
\text { bermanfaat } \\
\text { Sedikit } \\
\text { menguntun }\end{array}$ & & & \\
\hline
\end{tabular}

\begin{tabular}{|c|c|c|c|}
\hline $\begin{array}{l}\text { Bersedia } \\
\text { melakukan } \\
\text { skrining } \\
\text { untuk kanker } \\
\text { serviks }\end{array}$ & $\begin{array}{c}226 \\
(79.3)\end{array}$ & $228(80.8)$ & 0.52 \\
\hline Skrining & $30(10.5)$ & $49(17.3)$ & 0.02 \\
\hline kanker & $27(9.5)$ & 45 (15.9) & 0.02 \\
\hline $\begin{array}{l}\text { serviks } \\
\text { Pap smear } \\
\text { IVA }\end{array}$ & $3(1.0)$ & $4(1.4)$ & 0.69 \\
\hline $\begin{array}{l}\text { Alasan tidak } \\
\text { melakukan }\end{array}$ & $15(5.3)$ & & \\
\hline skrining & - & $40(14.1)$ & $<0.00$ \\
\hline Takut akan & & & 1 \\
\hline $\begin{array}{l}\text { hasil yang } \\
\text { positif }\end{array}$ & $\begin{array}{c}85(29.9) \\
12(4.3)\end{array}$ & $\begin{array}{c}104(36.7) \\
24(8.5)\end{array}$ & 0.07 \\
\hline Tidak ada & 37 (13) & $46(16.2)$ & 0.06 \\
\hline gejala & $9(3.2)$ & $0(0)$ & 0.3 \\
\hline Biaya & 118 & $0(0)$ & 0.001 \\
\hline skrining & $(41,4)$ & $81(28.6)$ & 0.001 \\
\hline $\begin{array}{ll}\text { Jarak } & \text { ke } \\
\text { tempat } & \\
\text { skrining } & \end{array}$ & - & & 0.001 \\
\hline Takut sakit & & & \\
\hline $\begin{array}{ll}\text { Tidak } & \text { tau } \\
\text { apapun } & \\
\text { tentang } & \\
\text { skrining } & \end{array}$ & & & \\
\hline $\begin{array}{l}\text { Tidak tau } \\
\text { tempat bisa } \\
\text { melakukan } \\
\text { skrining }\end{array}$ & & & \\
\hline
\end{tabular}

Kemauan untuk skrining kanker serviks relatif tinggi pada awal, 226 (79,3\%), tetapi tidak banyak perubahan yang diamati setelah intervensi, 228 (80,8\%). Ada peningkatan statistik yang signifikan dalam tingkat skrining untuk kanker serviks setelah intervensi $(\mathrm{p}=0,02)$. Proporsi peserta yang diskrining untuk kanker serviks meningkat dari $30(10,5 \%)$ sebelum intervensi menjadi $49(17,3 \%)$ setelah intervensi.

\section{Hubungan antara karakteristik sosio- demografi dan skrining kanker serviks}

Tabel 3. Faktor sosiodemografis terkait dengan praktik skrining untuk kanker serviks

\begin{tabular}{ccc}
\hline $\begin{array}{c}\text { Variabel sosio } \\
\text { demografi }\end{array}$ & $\begin{array}{c}\text { Screening rate } \\
\text { for cervical } \\
\text { cancer }(\mathbf{N}=\mathbf{4 9}) \\
\mathbf{n}(\%\end{array}$ & $\begin{array}{c}\boldsymbol{p} \text { - } \\
\text { value }\end{array}$ \\
\hline Usia & $4(8.2)$ & 0.33 \\
$25-34$ &
\end{tabular}




\begin{tabular}{|c|c|c|}
\hline $35-44$ & $10(20.4)$ & \\
\hline $45-54$ & $28(57.1)$ & \\
\hline$>54$ & $7(14.3)$ & \\
\hline \multicolumn{3}{|l|}{ Status menikah } \\
\hline Menikah & 40 (81.6) & 0.03 \\
\hline Belum & $5(10.2)$ & \\
\hline $\begin{array}{l}\text { menikah/Cerai/ } \\
\text { terpisah }\end{array}$ & $4(8.2)$ & \\
\hline \multicolumn{3}{|l|}{ Janda } \\
\hline Status & & $<0.001$ \\
\hline Pendidikan & $0(0)$ & \\
\hline SD & $0(0)$ & \\
\hline SMP & 49 (100) & \\
\hline \multicolumn{3}{|l|}{ SMA } \\
\hline \multicolumn{3}{|l|}{ Status Pekerjaan } \\
\hline Tidak bekerja & $5(10.2)$ & $<0.001$ \\
\hline Mahasiswa & $1(2)$ & \\
\hline Bekerja & $43(87.8)$ & \\
\hline \multicolumn{3}{|l|}{ Paritas } \\
\hline Tidak & $1(2.0)$ & $<0.001$ \\
\hline anak & $10(20.4)$ & \\
\hline $1-2$ & $27(55.1)$ & \\
\hline $3-4$ & $11(22.4)$ & \\
\hline$\geq 5$ & & \\
\hline
\end{tabular}

Tabel 3 menunjukkan hubungan antara sosio-demografi responden dan praktik skrining kanker serviks mereka. Tidak ada perbedaan yang signifikan dalam praktik skrining di antara responden dengan kategori usia yang berbeda. Ada perbedaan yang signifikan secara statistik dalam praktek skrining kanker serviks antara responden dengan status perkawinan yang berbeda, tingkat pendidikan, status pekerjaan dan paritas $(p<0,05)$. Wanita yang sudah menikah lebih mungkin melakukan skrining untuk kanker serviks daripada yang lain. Dari 49 responden yang melakukan skrining untuk kanker serviks, 40 $(81,6 \%)$ sudah menikah. Hanya mereka yang berpendidikan tinggi yang pernah melakukan skrining untuk kanker serviks, 49 $(100 \%)$. Wanita yang dipekerjakan 43 $(87,8 \%)$ dan memiliki lebih banyak (3-4) anak lebih mungkin untuk melakukan skrining untuk kanker serviks, 27 (55,1\%).

\section{Regresi logistik dari faktor-faktor yang terkait dengan skrining untuk kanker serviks}

Tabel 4 menunjukkan analisis regresi faktor yang terkait dengan skrining untuk kanker serviks di antara wanita yang telah diskrining untuk kanker serviks setelah intervensi. Peluang skrining untuk kanker serviks 3,3 kali lebih banyak pada wanita menikah dan 5,8 kali lebih banyak pada wanita yang belum pernah menikah dibandingkan mereka yang menjanda ( $\mathrm{p}$ $<0,05)$. Wanita yang memiliki 1-2 anak memiliki kemungkinan 2,4 kali lebih tinggi untuk menjalani skrining kanker serviks dibandingkan mereka yang tidak memiliki anak; dan mereka yang memiliki 3-4 anak memiliki kemungkinan 4,99 kali lebih tinggi untuk menjalani skrining kanker serviks dibandingkan mereka yang tidak memiliki anak.

Tabel 4. Analisis regresi faktor yang terkait dengan skrining untuk kanker serviks pasca intervensi dalam kelompok studi

\begin{tabular}{|c|c|c|c|c|c|}
\hline \multirow{2}{*}{ Variabel } & \multirow{2}{*}{$\begin{array}{c}\text { Koefisien } \\
\text { tidak } \\
\text { standar }\end{array}$} & \multirow{2}{*}{ OR } & \multirow{2}{*}{$\begin{array}{c}p- \\
\text { value }\end{array}$} & \multicolumn{2}{|c|}{$\begin{array}{c}\text { 95\% C.I. } \\
\text { for OR }\end{array}$} \\
\hline & & & & $\begin{array}{c}\text { Rend } \\
\text { ah }\end{array}$ & $\begin{array}{l}\text { Tin } \\
\text { ggi }\end{array}$ \\
\hline \multicolumn{6}{|l|}{ Usia } \\
\hline $25-34$ & & & 0.431 & & \\
\hline $35-44$ & 0.083 & 1.086 & 0.847 & 0.468 & 2.52 \\
\hline $45-54$ & -0.044 & 0.957 & 0.922 & 0.395 & 5 \\
\hline$>54$ & -0.870 & 0.419 & 0.167 & 0.122 & 2.31 \\
\hline Konsta & -1.482 & 0.227 & 0.000 & & 8 \\
\hline $\mathrm{n}$ & & & & & $\begin{array}{c}1.44 \\
0\end{array}$ \\
\hline \multicolumn{6}{|l|}{ Status } \\
\hline $\begin{array}{l}\text { Pernik } \\
\text { ahan }\end{array}$ & 1.204 & 3.333 & $\begin{array}{l}0.042 \\
0.028\end{array}$ & 1.142 & 9.73 \\
\hline Janda & 1.764 & 5.833 & 0.018 & 1.361 & 1 \\
\hline $\begin{array}{l}\text { Menik } \\
\text { ah }\end{array}$ & -2.639 & 0.071 & 0.000 & & $\begin{array}{c}24.9 \\
96\end{array}$ \\
\hline $\begin{array}{l}\text { Tidak } \\
\text { menika } \\
\text { h } \\
\text { Konsta } \\
\text { n }\end{array}$ & & & & & \\
\hline \multicolumn{6}{|l|}{$\begin{array}{l}\text { Pendidik } \\
\text { an }\end{array}$} \\
\hline SD & 0.000 & 1.000 & 1.000 & 0.000 & - \\
\hline SMP & 20.077 & 5.242 & 0.998 & 0.000 & - \\
\hline SMA & 21.203 & 0.000 & 0.998 & & \\
\hline \multicolumn{6}{|l|}{$\begin{array}{l}\text { Konsta } \\
\mathrm{n}\end{array}$} \\
\hline Status & & & 0.448 & & \\
\hline Pekerjaa & -1.878 & 0.153 & 0.104 & 0.016 & 1.47 \\
\hline $\mathrm{n}$ & -20.247 & 0.000 & 0.997 & 0.000 & 3 \\
\hline Tidak & -0.333 & 0.717 & 0.547 & 0.242 & - \\
\hline Bekeja & -0.956 & 0.385 & 0.385 & & 2.12 \\
\hline Wiras & & & & & 1 \\
\hline wasta & & & & & \\
\hline Swasta & & & & & \\
\hline Konsta & & & & & \\
\hline $\mathrm{n}$ & & & & & \\
\hline Paritas & & & & & \\
\hline Tidak & & & 0.002 & & \\
\hline
\end{tabular}




$\begin{array}{lccccc}\text { ada } & 0.896 & 2.449 & 0.414 & 0.285 & 21.0 \\ 1-2 & 0.896 & 2.449 & 0.414 & 0.285 & 32 \\ 3-4 & 0.182 & 1.200 & 0.867 & 0.142 & 21.0 \\ \geq 5 & -2.485 & 0.083 & 0.017 & & 32 \\ \text { Konsta } & & & & & 10.1 \\ \mathrm{n} & & & & & 19 \\ & & & & & \\ \end{array}$

Sebagian besar dari peserta tidak menganggapnya seserius kanker lain atau menganggap diri mereka berisiko menderita kanker. Ini bisa menjelaskan temuan dasar dari tingkat skrining kanker serviks yang sangat rendah. Kontak yang sering dilakukan oleh perempuan dengan layanan kesehatan harus memberikan kesempatan unik bagi petugas kesehatan untuk memberikan pendidikan kesehatan tentang kanker serviks, skrining kanker serviks, tempat layanan kesehatan yang menawarkan skrining oportunistik (Ndikom \& Ofi, 2012; Ncube et al., 2015). Di antara responden yang pernah melakukan skrining untuk kanker serviks, metode skrining yang paling umum digunakan adalah tes Pap smear.

Persepsi wanita dan praktik skrining kanker serviks ditingkatkan dengan pendidikan kesehatan sebaya. Setelah menerima informasi yang komprehensif tentang risiko, dan manfaat skrining, para wanita tersebut dapat menilai status risiko mereka dan mengambil tindakan yang diperlukan. Ada perbedaan yang signifikan secara statistik terkait persepsi mereka akan tingkat keparahan kanker serviks, risiko individu terkena penyakit dan manfaat skrining. Berdasarkan difusi teori inovasi persepsi, responden tentang manfaat skrining untuk kanker serviks berubah (Ntemana \& Olatokun, 2012). Setelah pendidikan kesehatan sebaya, lebih banyak wanita menganggap skrining bermanfaat. Meskipun perubahan yang diamati dalam praktiknya kecil, peningkatan yang berkelanjutan dapat diharapkan dari waktu ke waktu jika pendidikan kesehatan sebaya terus diberikan berulang kali. Tujuan akhir dari pendidikan kesehatan yang diperkuat adalah perubahan perilaku yang bertahan lama (Little et al., 2016). Ini dan lebih banyak lagi dapat dicapai informasi tentang kanker serviks dan manfaat deteksi dini melalui skrining terus menerus diberikan.

Status pernikahan, tingkat pendidikan, status pekerjaan dan paritas semuanya secara signifikan terkait dengan praktik skrining untuk kanker serviks. Wanita yang bekerja, menikah, pernah melahirkan dan memiliki tingkat pendidikan yang lebih tinggi lebih mungkin melakukan skrining untuk kanker serviks. Karena perempuan yang bekerja mencari nafkah, mereka lebih cenderung mampu membeli layanan kesehatan preventif daripada mereka yang menganggur. Dibandingkan dengan perempuan yang kurang berpendidikan, perempuan yang berpendidikan memilih memanfaatkan layanan kesehatan preventif, setelah diberitahu implikasi dari pilihan mereka. Wanita yang telah menikah lebih mungkin untuk melakukan skrining daripada mereka yang belum menikah dengan alasan seperti memiliki dukungan sosial dan keuangan dari pasangan (Tran et al., 2016). Ketiga faktor ini terkait erat dengan keterjangkauan dan menjelaskan perbedaan antara praktik skrining untuk kanker serviks dan kesediaan untuk melakukan skrining.

Populasi penelitian terdiri dari wanita usia produktif di kecamatan Dau yang menunjukkan bahwa beberapa faktor sosial dan budaya turut memengaruhi perilaku dan pengaruhnya tidak dapat diukur.

\section{Simpulan}

Kesediaan untuk melakukan skrining kanker serviks cukup tinggi di antara peserta penelitian. Pendidikan kesehatan sebaya adalah strategi yang efektif untuk meningkatkan persepsi wanita tentang manfaat deteksi dini kanker serviks dan praktik skrining kanker serviks. Pendidikan kesehatan sebaya juga terbukti efektif dalam mengatasi masalah faktor budaya dan sosial yang mempengaruhi perubahan perilaku. Pendidikan kesehatan sebaya harus dimasukkan dalam komponen promosi kesehatan dari rencana pengendalian kanker serviks, karena dapat berguna untuk memastikan perilaku skrining kanker serviks yang lebih baik. 


\section{Daftar Pustaka}

Ahmed, S. A., Sabitu, K., Hadejia, S., \& Ahmed, R. (2014). Knowledge and Practice of Cervical Cancer Screening amongst Nurses in Ahmadu Bello University Teaching Hospital Zaria. Research on Humanities and Social Sciences, 4(27), 33-36. https://doi.org/10.1.1.664.1432

Allemani, C, Matsuda, T., Di Carlo, Harewood, R., Stiller, C., \& Ogunbiyi, O. (2018). Global surveillance of trends in cancer survival 200014 (CONCORD-3): analysis of individual records for 37513025 patients diagnosed with one of 18 cancers from 322 population-based registries in 71 countries. The Lancet, 391(10125), 1023-1075. https://doi.org/10.1016/S0140-6736(17)333263

Allemani, Claudia, Weir, H. K., Carreira, H., Harewood, R., Spika, D., Wang, X.-S., Bannon, F., Ahn, J. V, Johnson, C. J., Bonaventure, A., Marcos-Gragera, R., Stiller, C., Silva, G., Chen, W.-Q., Ogunbiyi, O., Rachet, B., Soeberg, M. J., Hui You, Matsuda, T., ... Coleman, M. P. (2015). Global surveillance of cancer survival 1995-2009: analysis of individual data for 25 676887 patients from 279 population-based registries in 67 countries (CONCORD-2). The Lancet, 385(9972), 977-1010. https://doi.org/10.1016/S0140-6736(14)620389

Amin, Y., Mulawardhana, P., \& Erawati, D. (2015). Demografi, Respon Terapi dan Survival rate Pasien Kanker Serviks Stadium III-IVA yang Mendapat Kemoterapi Dilanjutkan Radioterapi. Majalah Obstetri \& Ginekologi, 23(3), 97. https://doi.org/10.20473/mog.v23i3.2074

Dinengsih, S., Sitanggang, E., \& Nasional, U. (2018). Analisis Faktor Prilaku Deteksi Dini Kanker Serviks dengan Metode IVA ( Inspeksi Visual Asam Acetat ) di Puskesmas Kota Padang. Promosi Kesehatan Indonesia, 14(1), 68-80.

Ferlay, J., Ervik, J., Lam, F., Colombet, M., Mery, L., Piñeros, M., Znaor, A., Soerjomataram, \& Bray, F. (2019). Estimating the global cancer incidence and mortality in 2018: GLOBOCAN sources and methods. Int J Cancer, 8(144), 1941-1953. https://doi.org/https://doi.org/10.1002/ijc.31937

Kementrian Kesehatan Republik Indonesia. (2018). Keputusan Menteri Kesehatan Republik Indonesia No HK.01.07/MENKES/349/2018 tentang Pedoman Nasional Pelayanan Kedokteran Tata Laksana Kanker Serviks. Kementrian Kesehatan RI. http://kanker.kemkes.go.id/guidelines/PNPKSe rviks.pdf

Little, L., Sillence, E., \& Joinson, A. (2016). Behavior Change Research and Theory: Psychological and Technological Perspectives. Academic Press.
Luh, N., Puspita, G., \& Sulantara, I. K. Y. (2018). Pengaruh PEER Education Terhadap Minat WUS Melakukan IVA di Banjar Tegal Desa. Kutambahan-Kab. Buleleng. Bali Medika Journal, 5(2), 221-230.

Ncube, B., Bey, A., Knight, J., Bessler, P., \& Jolly, P. E. (2015). Factors associated with the uptake of cervical cancer screening among women in Portland, Jamaica. North American Journal of Medical Sciences, 7(3), 104-113. https://doi.org/10.4103/1947-2714.153922

Ndikom, C. M., \& Ofi, B. A. (2012). Awareness, perception and factors affecting utilization of cervical cancer screening services among women in Ibadan, Nigeria: A qualitative study. Reproductive Health, 9(1), 1-8. https://doi.org/10.1186/1742-4755-9-11

Ntemana, T. J., \& Olatokun, W. (2012). Analyzing the Influence of Diffusion of Innovation Attributes on Lecturers' Attitude Towards Information and Communication Technologies. Human Technology An Interdisciplinary Journal On Humans In ICT Environments, 8(2), 179-197. https://doi.org/10.17011/ht/urn.201211203034

Nurhadi, Z. F. (2017). Teori Komunikasi Kontemporer (I). Kencana.

Oyervides-Muñoz, M. A., Pérez-Maya, A. A., Rodríguez-Gutiérrez, H. F., Gómez-Macias, G. S., Fajardo-Ramírez, O. R., Treviño, V., Barrera-Saldaña, H. A., \& Garza-Rodríguez, M. L. (2018). Understanding the HPV integration and its progression to cervical cancer. Infection, Genetics and Evolution, 61(January 2020), 134-144. https://doi.org/10.1016/j.meegid.2018.03.003

Pusat Data dan Informasi KemenKes RI. (2015). Situasi Penyakit Kanker. Buletin Jendela Data Dan Informasi Kesehatan, 1, 8-9.

Puspita, R. (2019). BKKBN: Deteksi Dini Kanker Serviks Baru 5 Persen. Republica.Co.Id. https://www.republika.co.id/berita/puqw5f428/ bkkbn-deteksi-dini-kanker-serviks-baru-5persen

Siagian, E. (2015). Faktor-faktor yang berhubungan dengan motivasi pemeriksaan pap smear pada karyawati. Skolastik Keperawatan, 1(1), 52-56.

Tran, B. X., Hwang, J., Nguyen, L. H., Nguyen, A. T., Latkin, N. R. K., Tran, N. K., Thuc, V. T. M., Nguyen, H. L. T., Phan, H. T. T., Le, H. T., Tran, T. D., \& Latkin, C. A. (2016). Impact of socioeconomic inequality on access, adherence, and outcomes of antiretroviral treatment services for people living with HIV/AIDS in Vietnam. PLoS ONE, 11(12), 1-13. https://doi.org/10.1371/journal.pone.0168687

Utami, N. T. S. (2013). Deteksi Dini Kanker Serviks: Studi Cross Sectional pada Ibu Rumah Tangga di Pedesaan. Samodra Ilmu, 7(2), 133-141.

WHO. (2012a). Health education: theoretical 
concepts, effective strategies and core competencies: a foundation document to guide capacity development of health educators. http://applicationsemrowhoint/dsaf/EMRPUB_ 2012_\%0AEN_1362pdf

WHO. (2012b). Health education: theoretical concepts, effective strategies and core competencies. A foundation document to guide capacity development of health educators. https://applications.emro.who.int/dsaf/EMRPU B_2012_EN_1362.pdf

World Health Organization. (2019). The Global Cancer Observatory, . Globocan 2018. https://gco.iarc.fr/today/data/factsheets/populati ons/360-indonesia-fact-sheets.pdf

Zhang, X., Yu, P., Yan, J., \& Spil, T. (2015). Using diffusion of innovation theory to understand the factors impacting patient acceptance and use of consumer e-health innovations: a case study in a primary care clinic. BMC Health Service Research, 15(71). https://doi.org/https://dx.doi.org/10.1186\%2Fs1 2913-015-0726-2 